\title{
Cartel, arte y patrimonio durante la guerra civil española: Significación del cartel dentro del patrimonio cultural
}

\author{
Federico Castro Morales \\ Profesor Titular $\mathrm{H}^{\text {a }}$ del Arte \\ Universidad Carlos III de Madrid
}

\section{Carteles y posters: HACIA UNA DEFINICIÓN}

José Martínez de Sousa define al cartel en su Diccionario de Bibliología y Ciencias afines como "Papel, pieza de tela o cualquier otro material con textos o figuras, colocado en lugar visible, que sirve de anuncio, aviso, publicidad". La proximidad de esta definición a las que podemos encontrar en el Diccionario de la Real Academia Española -"Papel, pieza de tela o lámina de otra materia escrita que contiene noticias, anuncios, propaganda, etc., y se exhibe eventualmente"-, o a la recogida por Julio Casares en el Diccionario ideológico de la lengua española -"Papel que se fija en un paraje público para hacer saber una cosa"-, desvelan el escaso desarrollo que han tenido las investigaciones biblioteconómicas sobre estos "materiales gráficos".

Etimológicamente, el término "cartel" parece derivar del italiano "cartello", aumentativo de "carta" -un sinónimo de "papel"-, lo cual nos sitúa ante la sugerencia de un soporte material de grandes dimensiones. En su inicio, los carteles se elaboraron con procedimientos manuales, pero pronto las formas manuscritas remitieron en favor de las impresas con cualquiera de las técnicas desarrolladas por las "artes gráficas". Se trata de producciones que no son únicas, sino múltiples, que las más de las veces tienen una utilización comercial, aunque también pueden tenerla ideológica e incluso estética.

\section{LOS CARTELES Y SUS TIPOLOGÍAS}

El proceso de desarrollo del cartel ha dado lugar al surgimiento de diversas tipologías:

El cartel comercial es el tipo más frecuente y con el que más familiarizados estamos ya que lo encontramos en ciudades y carreteras. Su finalidad es la de influir en los individuos para que compren determinados productos.
El cartel cultural pretende persuadir al público sobre convocatoria de eventos. No intenta manipular la realidad ni los sentimientos de las personas, tan sólo informa atractivamente sobre un hecho artístico. Dirigido a un sector restringido de la población, en la actualidad y paralelamente a la implantación social alcanzada por determinadas manifestaciones culturales como el cine, ha alcanzado una gran difusión. Se trata de la especialidad del cartel en la que el autor más se puede mostrar como artista.

El cartel comercial compartió una existencia bastante grata con el cartel cultural hasta la Primera Guerra Mundial. Entonces las necesidades de propaganda política en la retaguardia y en el frente, incidieron en el surgimiento y desarrollo del cartel político.

El cartel político guarda una estrecha relación con el ascenso del arte social. Desde los años finales de la Primera Guerra Mundial y durante la década de los veinte el arte occidental se había teñido de consignas sociales y populares. Junto al optimismo del art-decó, encontramos a los artistas del realismo social y crítico que, provenientes del expresionismo, cargan de denuncia social a la pintura.

El cartel artístico o poster cuenta con unas características peculiares: elección voluntaria, compra, visión a corta distancia, ausencia de slogan, permanencia prolongada, esteticismo creciente... Con este barbarismo, que debe entenderse como algo más que un sinónimo del término español "cartel", se define a una modalidad del cartel destinada a un consumo privado y decorativo, que ha consolidado una industria floreciente.

\section{EL PROCESO DEL CARTEL: AVANCE TÉCNICO Y ACEPTACIÓN SOCIAL}

El desarrollo del cartel ha estado vinculado a una serie de avances en las técnicas de estampación e impresión. La xilografía, el grabado y el aguafuerte hicieron posible el paso de una cultura de la imagen única a otra de la imagen múltiple, pero el proceso de impresión deterioraba la imagen original, viéndose limitado el número de copias. 


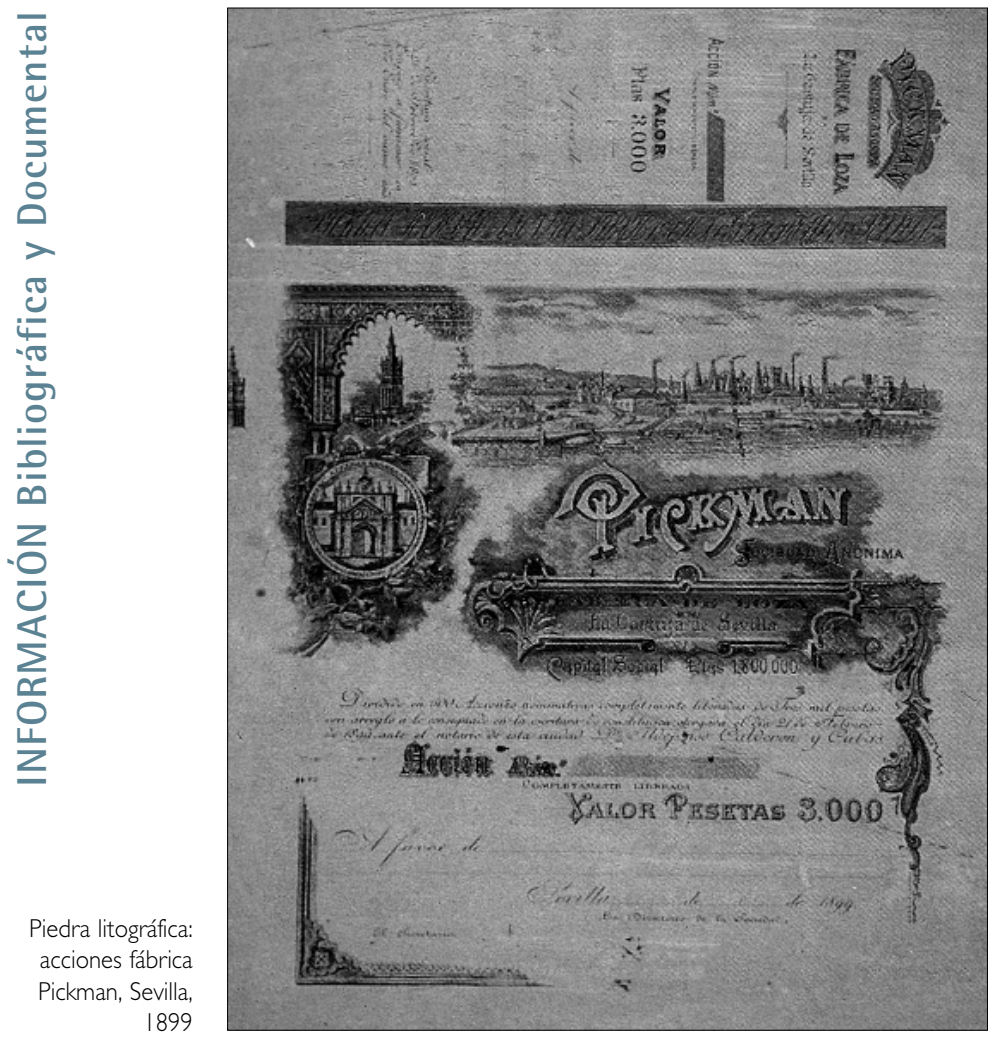

El gran paso se operó con la litografía: Alois Senefelder ideó en 1796 el sistema de estampación que hoy conocemos como litografía, que empleaba la piedra calcárea como soporte. La litografía sirvió a los intereses de los primeros periódicos ilustrados y facilitó sobremanera la estampación de impresos. Esta técnica, primero, y la aplicación del maquinismo alcanzado por la revolución industrial, después, fueron los responsables de la llamada “democratización de las imágenes": los sistemas de estampación fueron más perfectos, veloces y casi no producían deterioro del original en comparación con las técnicas anteriores basadas en la incisión que se practicaba en la superficie maleable de madera o metal.

En 1836 comenzó la aplicación de la cromolitografía con el procedimiento de rodillos; técnica que tuvo gran difusión en las Islas Británicas. Esta técnica será la responsable de la eclosión definitiva del cartel.

Cuando la industria de reproducción mecánica de las imágenes adquirió un nivel aceptable (diez mil imágenes por hora) y se comprobó el efecto que ejercían sobre la sociedad las imágenes de gran tamaño, impresas en colores y fijadas en la vía pública, se inició la irrupción del cartel en el ámbito urbano.

Los primeros carteles se situaban en mercados, cafés, ferias... Se exhibían en el interior de recintos públicos, pero luego poblaron las fachadas de los edificios y comenzaron a despegarlos para incorporarlos a la decoración interior de espacios privados. Antes de alcanzar el fin de siglo se realizaron reediciones de carteles comerciales para proceder a su venta, se organizaron exposiciones, e incluso, se publicó una historia del cartel. También se editó una revista bajo el título The Poster. Los carteles franceses, ingleses y belgas gozaron de un éxito que pronto compartieron los catalanes, alcanzando elevadas cotizaciones entre los coleccionistas británicos de finales del siglo XIX.

El boom del cartelismo se produjo a principios de este siglo, no sólo como la lógica consecuencia de las mejoras técnicas en la imprenta, sino también por la aparición de una nueva burguesía industrial que no tenía sus gustos ligados a las artes clásicas, y sentía una fuerte necesidad social de informar e informarse, comunicar y vender. Ante tales demandas no debe sorprender que el cartel se hubiera convertido en el gran género burgués.

Hay que destacar el interés creciente de la historia del arte por el cartel. No en vano, numerosos creadores y creadoras contemporáneos efectúan apropiaciones de elementos provenientes del cartel. Sin embargo, en esta ocasión vamos a centrar la atención sobre el cartel político, y más concretamente sobre el cartel de guerra, para concluir con la referencia a su manifestación en España.

\section{El CARTEl político en Europa}

Con el estallido en 1914 de la Primera Guerra Mundial y la Revolución Soviética de 1917, el cartel se instrumentalizó políticamente, sirviendo para expandir consignas y crear sentimientos colectivos. Durante el fascismo italiano y el nazismo alemán, los carteles se sumaron a la propaganda y culto a la personalidad de sus endiosados líderes. El cartel soviético suele exaltar los valores ideológicos.

La publicidad comercial, provoca la adquisición individual de objetos de consumo; por el contrario, la propaganda ideológica conmina a la lucha colectiva por la satisfacción de unos ideales $y$, por tanto, aunque compartan recursos retóricos, debemos concluir que les separa una seria disimilitud.

El cartel político lo producen los Estados, los partidos, los sindicatos, las confesiones religiosas y otros organismos, con el propósito de conseguir adeptos a sus ideas; o, para reafirmar el protagonismo de una institución. Los "productos" que se quiere hacer consumir, no son artículos materiales. Precisamente aquí está la gran diferencia respecto del cartel comercial, pero también en su fuerte carga connotativa, sentimental y emotiva.

Frente al cartel electoral en el que imperan los valores positivos, en una situación de enfrentamiento o de guerra, los carteles tanto en sus imágenes como en sus slogans se hacen más fuertes y agresivos, exaltan las banderas, colores y escudos propios y denigran a los de los contrincantes.

Los carteles políticos pueden clasificarse formalmente en tres grandes categorías:

- Carteles "pictoricistas" de signo realista: que están emparentados formalmente con el más tradicional realismo decimonónico, aunque también pueden adquirir tintes expresionistas 
- Carteles que desarrollan una línea formal coherente: acordes con los planteamientos formales de la vanguardia con la que conviven.

- Carteles caricaturescos y satíricos: el humor entró por derecho propio dentro de la cartelística de guerra, actuando como contrapunto frente a la seriedad y dramatismo propagandísticos. Humor y denuncia no están reñidos, especialmente a la hora de ridiculizar al enemigo. La ridiculización y la deformación satírica enlaza con la vieja tradición de lo grotesco.

- Fotomontajes: incorpora elementos de la fotografía al cartel, en ocasiones con una voluntad documental, en otras para crear asociaciones provocadoras. En Rusia se utilizó como arma propagandística; los dadaístas lo pusieron al servicio de la crítica social. John Heartfield (|89|1968) lo cargó de intencionalidad política: primero contra la República de Weimar y luego para reflejar la terrible ascensión del fascismo en Europa y la dictadura de Hitler. Trabajaba para la prensa comunista alemana y creía que los fotomontajes eran instrumentos políticos que debería utilizar la izquierda desde la perspectiva dialéctica del materialismo histórico.

\section{El CARTEL Político EN EsPaña}

En 1931 el cartel político, en cualquiera de su vertientes, prácticamente no existía en nuestro país. Experimentó un fuerte auge entre 1931 y 1939, paralelamente al proceso de politización de la sociedad española. El cartelismo tuvo un gran desarrollo en nuestra guerra civil por la situación en la que quedó el Estado como consecuencia de la rebelión militar.

Hay una desproporción entre el número de carteles republicanos y "nacionales" conservados. Esta diferencia es expresiva de la diferente importancia que ambos bandos dieron al cartel político: fundamental para los republicanos, casi inexistente entre los rebeldes.

Al haber quedado Valencia, Madrid y Barcelona en zona republicana y ser las ciudades con mayor desarrollo de la industria de las artes gráficas, se contaba con mayor facilidad para la impresión de carteles. Pero además de esa circunstancia, hay que destacar que durante la guerra el poder del Estado dependía de la voluntad de acción, de la disciplina y del combate del pueblo y en ese contexto la propaganda política era un arma imprescindible.

Por otro lado, el protagonismo de los partidos y los sindicatos en el gobierno del Estado determinó el surgimiento "desde abajo" de los principales aparatos de propaganda gráfica. Espontáneamente se organizaron colectivos de cartelistas (profesionales de la publicidad y pintores) a los que se sumaron voluntarios.

No hay que olvidar la vocación revolucionaria de los creadores, artistas e intelectuales, y que, como consecuencia de la rebelión, el Estado era a la vez gobierno y órgano que cohesionaba a la revolución popular. Los

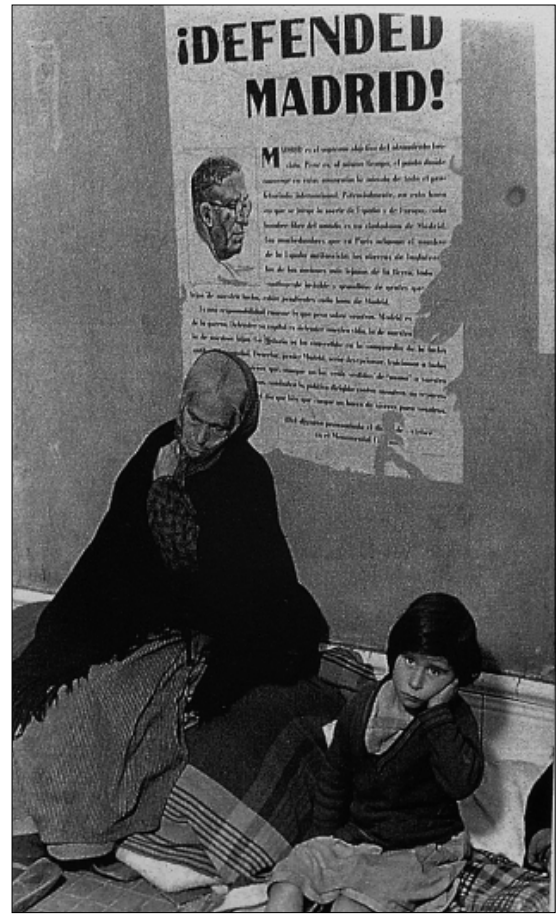

"¡Defended Madrid!", cartel en el andén de una estación del Metro
Alistaos en el glorioso $5^{\circ}$ Regimiento, ejemplo de "el cartel dentro del cartel"

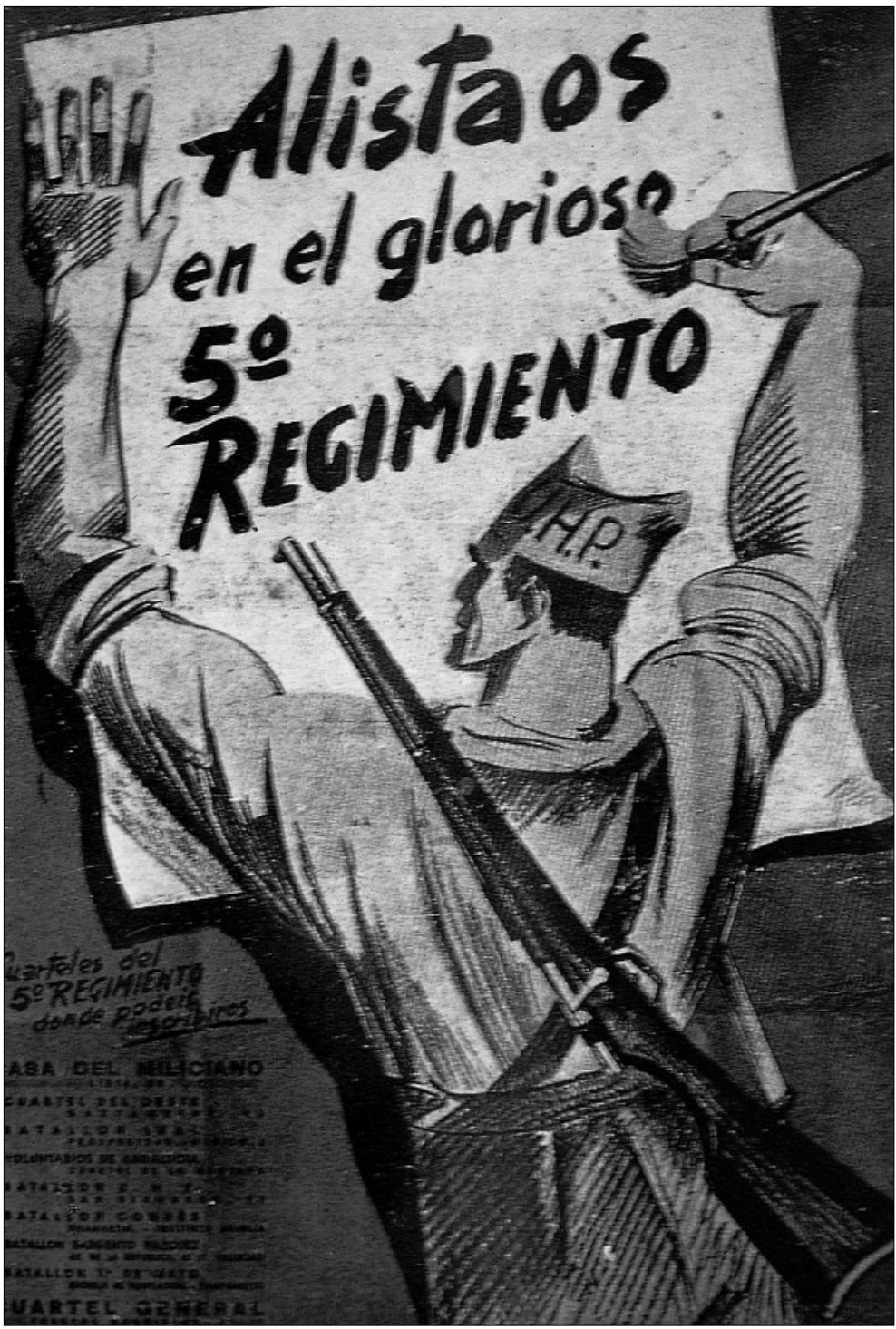


Sindicatos y partidos se convirtieron en entidades editoras y sus militantes distribuían y colocaban los carteles en las calles. Las empresas litográficas quedaron bajo el control de los obreros que impulsaban con entusiasmo la estampación de carteles.

El imperativo de la guerra hace que las ciudades españolas, de la noche a la mañana, quedaran convertidas en soportes para un arte popular: popular por su proceso de creación, por su producción industrial y por la participación masiva del público.

La conversión de todas las milicias en un ejército popular es uno de los rasgos básicos de la política republicana una vez pasados los primeros momentos de la guerra. Las milicias habían sido eficaces para apagar algunos alzamientos en las grandes ciudades, pero en la guerra convencional dejaban mucho que desear. A pesar del esfuerzo del gobierno, el ejército republicano jamás alcanzó la solidez y capacidad operativa que tuvo el de Franco.

nunca", de Josep

Renau. 1938

"La guerra ha terminado", de Paco Ribera.

1939
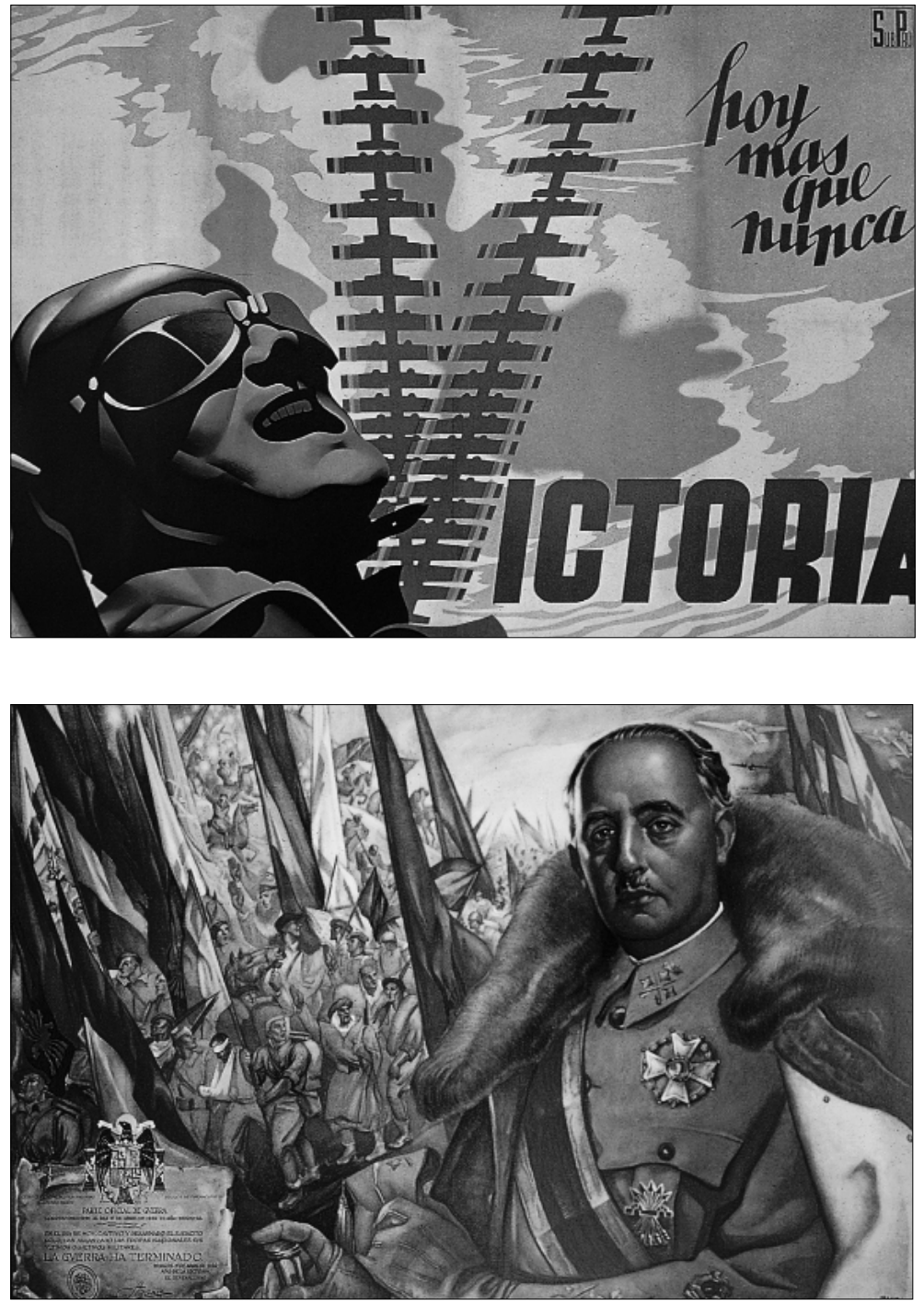

Por encargo de la Junta Delegada de Defensa de Madrid se realizaron numerosos carteles dirigidos a la tropa, en los que se trataba de inculcar disciplina a un ejército integrado por escasos efectivos militares y numerosos voluntarios. También a un sector de la población al que se intentaba inculcar una serie de valores cuyos referentes más sólidos se encontraban en la URSS, el país que dio su apoyo al ejército republicano.

Especial interés ofrece para el estudio del cartel de guerra en España la propaganda emprendida por el Partido Comunista. En ocasiones de gran calidad artística, como los realizados por Josep Renau.

Frente a la ingente producción cartelística republicana, la de los sublevados fue escasa. Fue precisamente a comienzos de 1938 cuando el aparato de propaganda franquista inició su labor más efectiva, bajo la dirección del falangista Ridruejo.

En líneas generales, el cartelismo de los "nacionales" rechazó las formas vanguardistas surgidas durante el siglo $X X$ para retomar modelos barroquizantes, con algunos detalles tomados de la Alemania nazi o de la Italia fascista. Cuando finalizó la guerra, encontramos una mayor profusión de carteles nacionales, muchos de ellos inspirados en los diseños de Carlos Sáenz de Tejada. En sentido estricto no se trata de carteles de guerra, sino de alegorías de la victoria.

Por lo general los carteles franquistas suelen ser retóricos y reiterativos en su exaltación de las insignias y banderas del bando vencedor en la guerra. En esta iconografía es frecuente un desmedido culto a la personalidad de Franco, venerándose su efigie en la búsqueda de una identidad para la Autarquía o exaltando su labor de gobierno con slogans carentes de contenido ideológico.

El cartel ideológico demostró ser durante la Guerra Civil un instrumento de confrontación eficaz. Y fueron muchos los artistas comprometidos más con uno que con el otro bando, quienes conformaron aquellas imágenes. El cartel político languideció durante el franquismo y no ha podido recomponerse como arte autónomo en el seno de nuestra joven democracia.

Sólo entonces el cartel pudo ser y fue una unidad cultural, un verdadero "signo" social. Existía la necesidad de persuadir sobre el cambio y la persuasión podía tener un carácter masivo. El cartel advertía sobre una realidad de hecho, modelaba una unidad de deseo y era capaz de materializar una filosofía común para el nuevo orden social al que se aspiraba.

\section{LOS CARTELES: ARTE, HISTORIA Y PATRIMONIO DOCUMENTAL}

Los carteles nos permiten detectar diversas versiones de la guerra. También los cambios de concepción que las fuerzas en contienda tienen del conflicto. Constituyen, por tanto, una fuente de información histórica eficaz pa- 
ra reconstruir la historia de las mentalidades en aquel trienio, aunque, en sentido estricto, no nos aporten datos históricos para la confección de una historia de los acontecimientos.

La significación histórica de los carteles fue valorada ya desde los años de la contienda. Desde principios de 1937, dentro de la policía y la guardia civil del bando "nacional" se organizó un "cuerpo especial" encargado de la represión de los vencidos, que procedió a la incautación sistemática de archivos, bibliotecas y otro material informativo de los partidos y entidades republicanas en las zonas que iban cayendo en manos de los "nacionales".

En 1937 se creó la Delegación de Asuntos Especiales, que delimitaba las funciones del "cuerpo especial" y lo hacía depender directamente de la Secretaría General del Jefe del Estado, y de la Delegación del Estado para la recuperación de Documentos. Puestas ambas bajo el mando de Marcelino de Ulíbarri, se sentaron las bases del actual archivo. Al finalizar la guerra se instalaron en Salamanca y en 1944 se fundieron las dos en la Delegación Nacional de Servicios Documentales, que continuó teniendo un carácter eminentemente policiaco hasta que, en 1977, se la hizo depender de la Dirección General de Patrimonio Artístico, Archivos y Museos, pasando en 1979 a integrarse en el Archivo Histórico Nacional como una sección independiente.

En la actualidad, la Sección Guerra Civil del Archivo Histórico Nacional de Salamanca cuenta con más de 700 carteles de guerra, un buen número de letreros murales impresos y una larga colección de calendarios. Es sin lugar a dudas el fondo más importante de carteles de la Guerra Civil española.

Los fondos mejor organizados son los de la Fundación Figueras (Centre d'Estudis d'Història Contemporànea), situado en Barcelona. El número de carteles que posee no es muy superior al de la Biblioteca de la Universidad Literaria de Valencia. Su fondo se ha publicado bajo el título Carteles de la República y la guerra civil. La Biblioteca de la Universidad Literaria de Valencia conserva material del que no existen copias en otros archivos. Aproximadamente la mitad son carteles valencianos.

La Biblioteca Nacional recoge en su Servicio de Dibujos y Grabados casi 500 carteles políticos y de guerra, editados entre 1931 y 1939, más algún ejemplar inmediatamente anterior o posterior a esos años, y tres "álbumes" editados durante la contienda. La colección fue adquirida en 1982 a un particular por el Centro Nacional del Tesoro Documental y Bibliográfico del Ministerio de Cultura para la Biblioteca Nacional. Completa la colección del Archivo Histórico Nacional (Sección Guerra Civil) de Salamanca. Existe un catálogo sistemático, publicado en 1990 por la propia Biblioteca Nacional, aunque la edición está agotada.

Para estudiar el fenómeno cartelista en Cataluña, resulta primordial la consulta de los fondos del Instituto Municipal de Historia de Barcelona y los de Montserrat. Por últi- mo, hay que mencionar colecciones privadas en el extranjero, especialmente en Estados Unidos y Amsterdam, aunque los fondos que albergan dichas colecciones son poco conocidos en nuestro país.

\section{LA DEFENSA DEL PATRIMONIO ARTístICO E HISTÓRICO ESPAÑOL DURANTE LA GUERRA CIVIL: SU REFLEJO EN LOS CARTELES}

Una de las acusaciones que más pesó sobre el bando perdedor de la Guerra Civil fue la de los enormes destrozos que habían cometido contra el Patrimonio Histórico. Aquí debe distinguirse entre la labor del gobierno de la República y los desmanes cometidos por algunos elementos del pueblo y la milicia.

Juan de Contreras, Marqués de Lozoya y Director General de Bellas Artes durante la Autarquía, escribía en fechas aún próximas al fin de la contienda:

"...el marxismo lo ha alterado todo, amontonando los objetos en almacenes inconmensurables, y es tarea del nuevo Estado el que cada cosa vuelva a su lugar... Afortunadamente nada se ha perdido y las colecciones del Estado se encuentran hoy íntegras como antes de 1936"

"Obreros de hoy respetad la labor de nuestros compañeros de ayer". Gráficas Valencia 1937

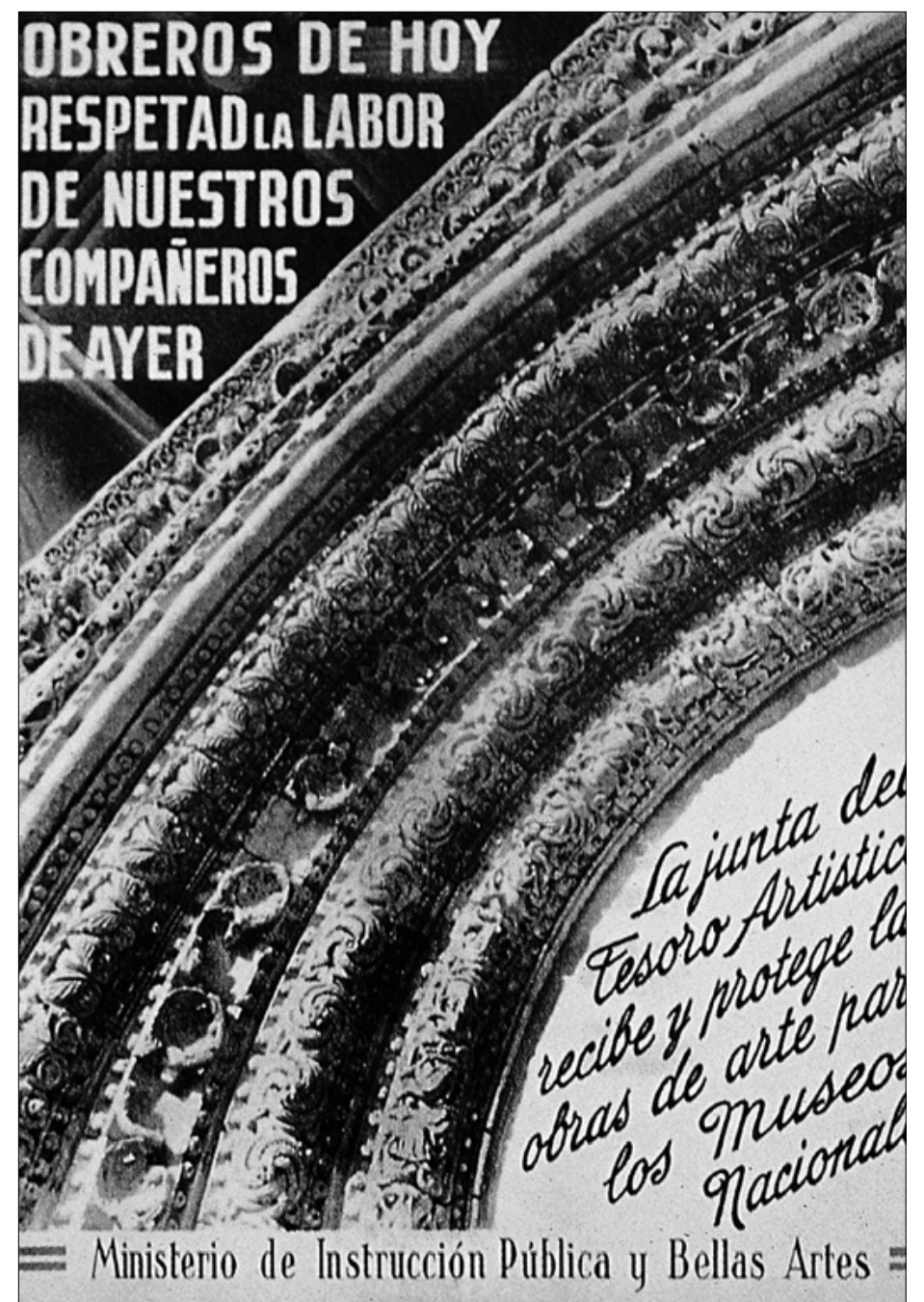


Este texto, fechado en 1945, nos sitúa ante la dimesión real del problema: el patrimonio propiedad del Estado fue perfectamente cuidado por el gobierno de la República y restituído por el del general Franco.

Uno de los personajes que más contribuyó a que no se perdiera nada fue el cartelista Josep Renau. Durante el gobierno de Francisco Largo Caballero, cuando el Partido Comunista tenía una gran presencia en el gabinete, pues contaba con dos ministerios, Jesús Hernández Tomás, ministro de Instrucción Pública y Bellas Artes, encomendó en 1936 a Renau la Dirección General de Bellas Artes. Aunque su nombramiento conllevó el abandono casi completo de la práctica del cartel, sobre él recayó una de las tareas más loables y a la vez más desconocidas de la República: organizar la defensa del patrimonio cultural de nuestro país.

Para apoyar esta labor se crearon en el territorio de la República las Juntas de Protección del Tesoro Artístico, que se encargaron de reunir las obras más representativas del Museo del Prado y otros museos españoles, así como objetos de los archivos y bibliotecas, que fueron evacuados por el puente del Jarama antes de que éste fuera abatido por el ejército de Franco (20 de noviembre de 1936). El patrimonio estatal viajó hacia Valencia, a donde se trasladó la sede del gobierno de la República, y más tarde al Castell de Figueres para, finalmente, abandonar

arte de España es un objetivo de la aviación fascista", de Ramón Gaya. 1937

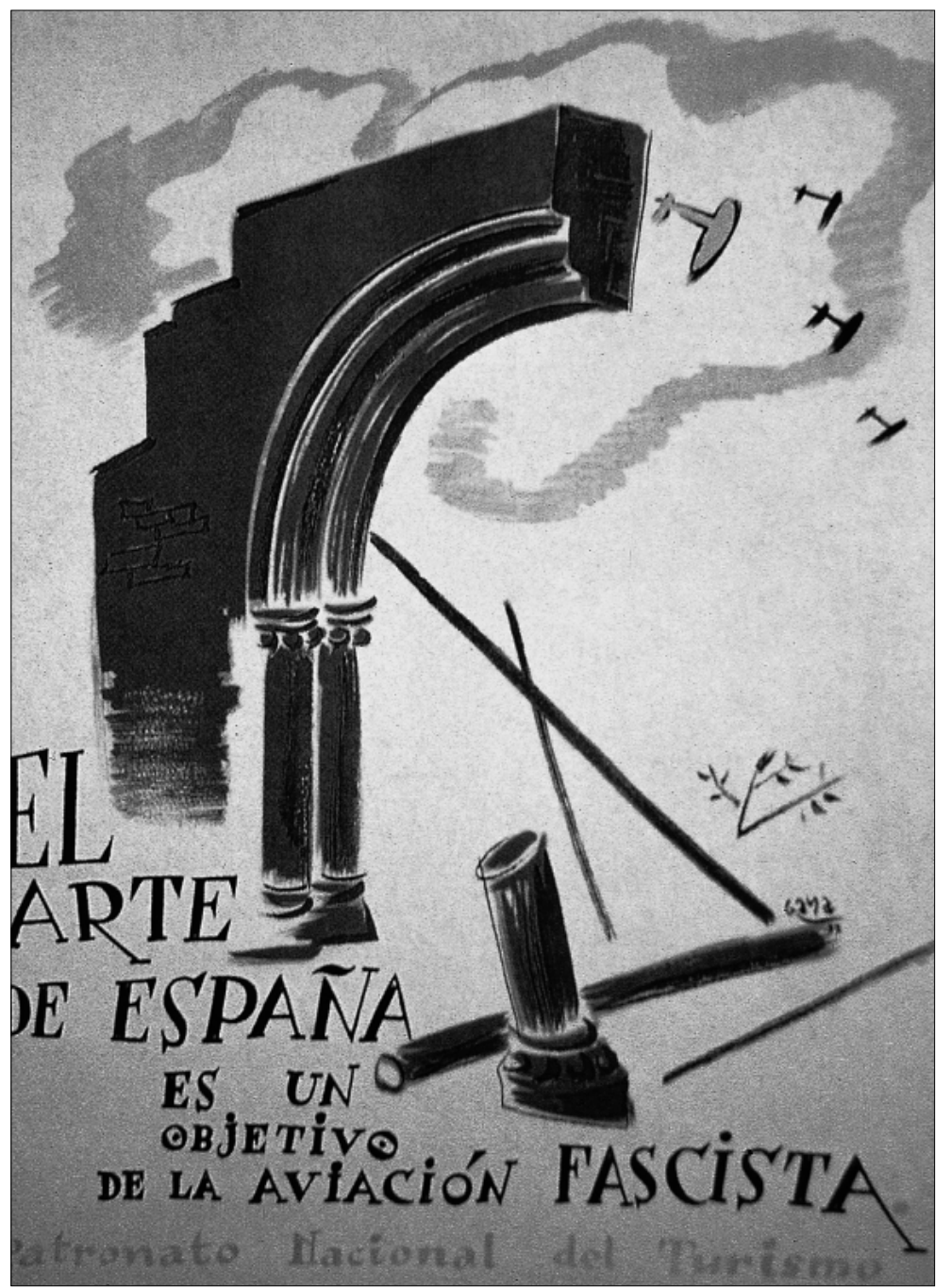

nuestro país en dirección a Ginebra donde fueron expuestas antes de ser devueltas a España, una vez hubo concluído la guerra.

Las labores de incautación y traslado de obras de arte eran vistas por los rebeldes como un peligro para el patrimonio español, pues suponían -o al menos les interesaba difundir esa idea- que las obras iban a acabar en Rusia.

Dentro de las medidas adoptadas por el gobierno para la defensa de este patrimonio hay que destacar la labor normativa que se llevó a cabo: Decreto de 25 de julio de 1936, Decreto de 12 de enero de 1937, Decreto de 16 de febrero de 1937 y Orden Ministerial de 5 de abril de 1937, todos tendentes a facilitar la incautación de bienes en peligro. Como característica común de esta normativa hay que destacar la intención constante por parte del Ministerio de Instrucción Pública y Bellas Artes de coordinar y centralizar todos los trabajos de defensa y extender el radio de acción de los organismo creados con el fin de aumentar la eficacia de estas medidas.

\section{TRABajo de Las Juntas de CONSERVACIÓN Y PROTECCIÓN DEL TESORO}

Desde los primeros disturbios civiles previos al despliegue de la aviación y la artillería, el gobierno de la república tomó una serie de medidas preventivas en los museos, bibliotecas y edificios de valor artístico e histórico: traslado de las obras a los sótanos, protección de los objetos de grandes dimensiones y de las partes frágiles de los edificios, apuntalamiento de estructuras...

El comienzo imprevisto de la guerra dificultó una serie de medidas preventivas que podrían haber evitado algunas imperfecciones. La República en un primer momento se encargó del Tesoro Artístico de Toledo, de hecho cuando la ciudad fue ocupada por las tropas de Franco estos tesoros se encontraban fuera de su emplazamiento original y en los sótanos de diferentes edificios. El cuadro del Entierro del Conde de Orgaz del Greco quedó en la misma iglesia, tendido sobre el suelo y protegido por abajo y arriba con gran cantidad de mantas alternadas con tablones, de modo que aunque el edificio se hubiera derrumbado, la pintura hubiera quedado indemne. Otros objetos de valor incalculable eran las vidrieras de la catedral.

Las Juntas de Conservación y Protección del Patrimonio en principio no se ocupaban de las obras pertenecientes a colecciones privadas, eclesiásticas y a los tesoros cuya tutela no competía a la jurisdicción del Estado. No obstante, el gobierno de la República tuvo que proteger aquellos bienes propiedad de la Iglesia de los desmanes cometidos por el pueblo, que veía en estos objetos la propiedad de sus enemigos dado el apoyo que amplios sectores de la Iglesia dieron a los rebeldes.

Encontrándose Josep Renau en París con motivo del montaje del Pabellón de España en la Exposición Universal de 1937, recibió el encargo del director de la 
Oficina Internacional de Museos para escribir un documento de carácter oficial en el que quedaran recogidos los trabajos de salvamento y preservación del Patrimonio Artístico e Histórico español que se habían impulsado ante la amenaza de la guerra. Fue presentado en París ante la Sociedad de Naciones y publicado por la Oficina Internacional de Museos. Este texto sirvió como modelo a otros países europeos a la hora de adoptar medidas para la preservación de sus respectivos patrimonios nacionales.

Dicho documento se convirtió en la mejor propaganda para el gobierno republicano, casi más efectivo que el propio Pabellón. Lo presentó en una Conferencia Internacional para especialistas que congregó a los directores y conservadores de museos de todos los países miembros de la Sociedad de Naciones, incluídos los países que estaban bombardeando nuestro patrimonio.

A su vez, los republicanos, denunciaban en sus carteles que la destrucción de iglesias y otras piezas artísticas de debía a los bombardeos italianos y alemanes. Hay que recordar que España sirvió de campo de prueba para la aviación alemana e italiana y los nuevos medios de destrucción masiva que ocasionaron grandes pérdidas materiales y humanas.

\section{EL CARTEL: CONSIGNAS PARA la defensa del Patrimonio}

Las medidas de defensa del patrimonio nacional no se hubieran llevado a cabo sin el apoyo y esfuerzo desinteresado de un amplio sector de la población. En líneas generales el pueblo respetó y protegió aquellas obras de propiedad estatal que albergaban los museos, bibliotecas y archivos. Este respeto por el patrimonio nacional estuvo estimulado por el gobierno de la República, desde antes del comienzo de la guerra, a partir de las Misiones Pedagógicas, iniciadas en 1931. La lucha contra el analfabetismo y la defensa de la cultura fueron dos pilares fundamentales de los gobiernos de la República antes y durante la contienda.

Con la guerra se organiza una campaña de propaganda cultural en la retaguardia para persuadir a la sociedad de la necesidad de defender y salvar a cualquier costa los edificios históricos, las iglesias, los archivos parroquiales. En esta misión destacaron los jóvenes pertenecientes a la F.U.E. y a las escuelas de Bellas Artes, que realizaron numerosos carteles y pinturas murales dirigidos a la opinión pública, con el propósito de evitar que se cometieran actos de pillaje y saqueos en las iglesias o en palacetes privados. A su labor se debe la difusión de consignas como las siguientes:

“Pueblo, antes de destruir un objeto cualquiera, infórmate!

"¡No destruyas ningún dibujo, ni grabado, ni pintura. Consérvalo para el Tesoro Nacional!

Un objeto religioso puede ser al mismo tiempo UNA OBRA DE ARTE. Consérvalo para el Tesoro Nacional".

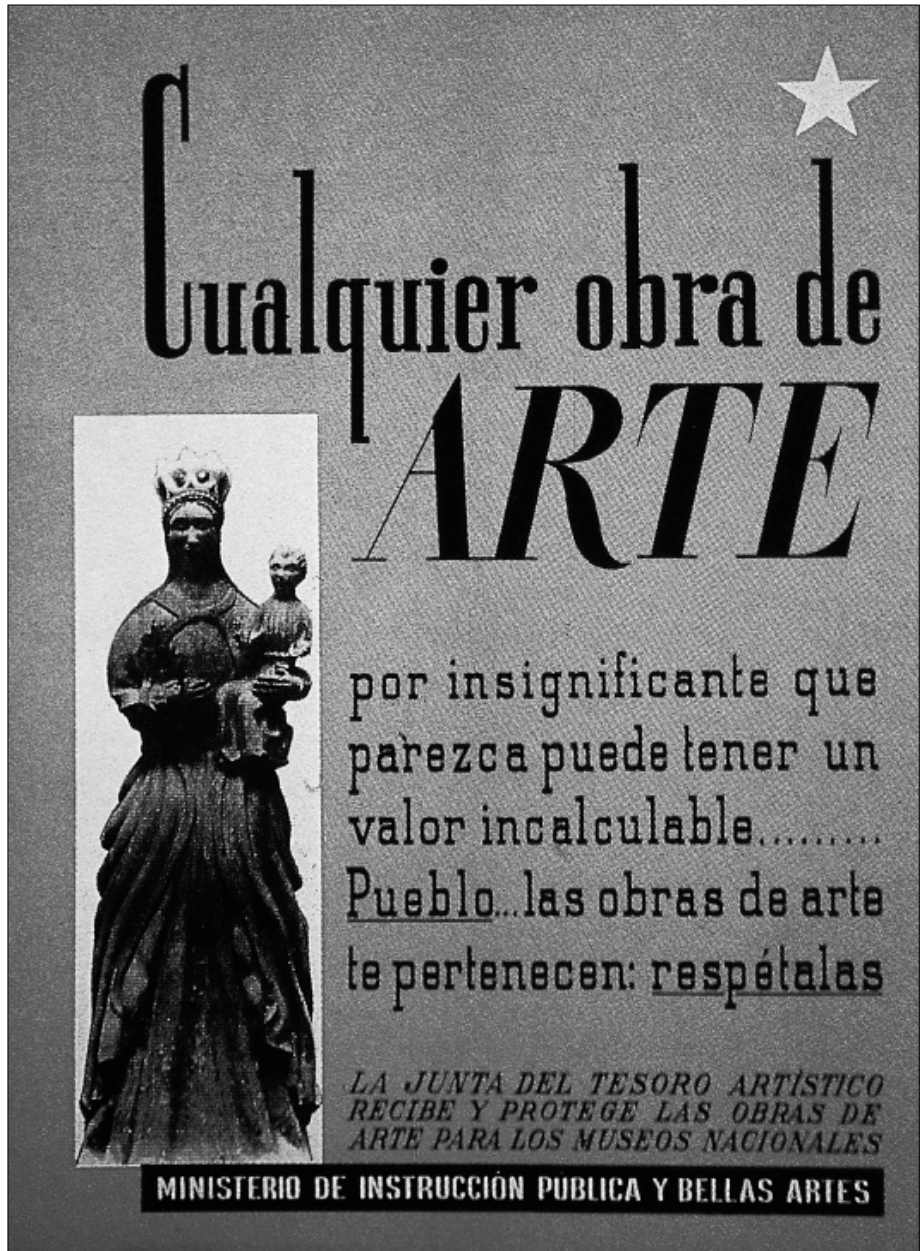

Especialmente la última consigna desvela donde se encontraba la debilidad en el sistema de protección del patrimonio: los bienes propiedad de la iglesia y de particulares era vistos como objeto de destrucción por quienes se manifestaban con intolerancia contra personas o instituciones que apoyaban a las tropas sublevadas. El peligro estaba, por tanto, en el pueblo, entre los milicianos y en sectores incontrolados.

El Ministerio de Instrucción Pública consciente de la importante labor de protección que había de jugar la población, editó una serie de folletos y carteles propagandísticos para popularizar las consignas de defensa del patrimonio artístico español. Al mismo esfuerzo contribuyó también el Patronato Nacional de Turismo.

Formar a la población, incluso en tiempo de guerra, constituyó una de las metas perseguidas por partidos y fuerzas sindicales; pero también por el ejército. Aunque el problema era común a ambos bandos, no es de extrañar que el ejército popular republicano tuviese en su seno hombres que desconocían los más elementales rudimentos culturales. Existía un problema estructural difícil de salvar y que restaba eficacia a la difusión escrita: España seguía siendo un país mayoritariamente campesino, con zonas rurales muy atrasadas y un elevado porcentaje de analfabetos.

Como continuidad del proyecto de escolarización que el régimen republicano había puesto en marcha en 1931,
Cualquier obra de arte por insignificante que parezca puede tener un valor incalculable... Pueblo... las obras de arte te pertenecen: respétalas". Gráficas Valencia, c. 1937 


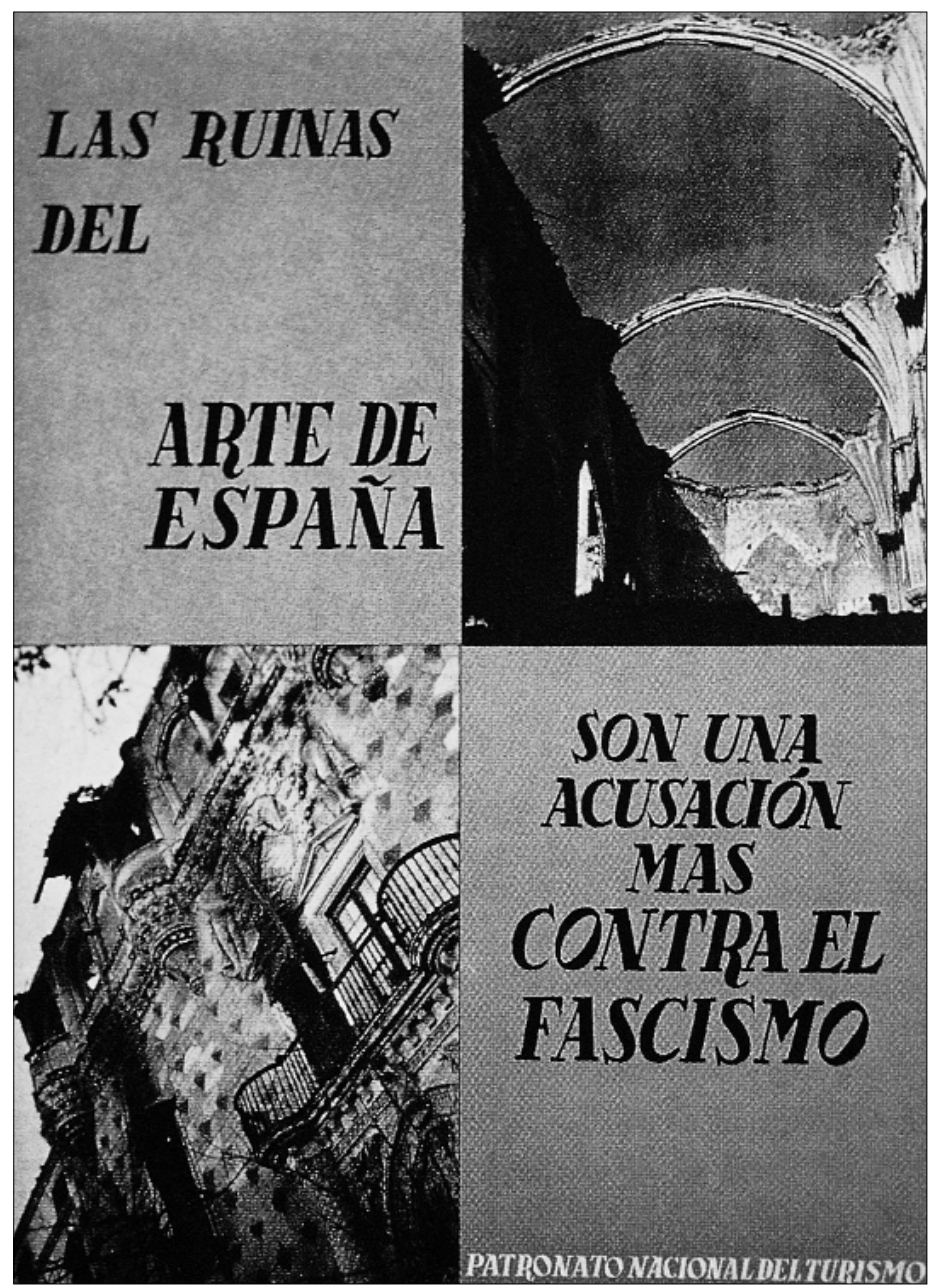

Las ruinas del arte de España son una acusación más contra el fascismo. c. 1937 durante la guerra se crearon las Milicias de la Cultura. Su importante labor requiere un tratamiento monográfico. Similar atención merecería la gran figura del cartel de guerra en España, Josep Renau. A él se debe que en plena contienda se comience a teorizar sobre el cartel político en España. Una conferencia titulada La función social del cartel republicano, que pronunció en la Universidad de Valencia poco después del traslado del Gobierno de la República provocó una fértil polémica con el pintor e ilustrador Ramón Gaya de la que se deducen aspectos sustanciales para comprender este fenómeno.

En esta ocasión hemos querido centrarnos en el cartel desde la perspectiva del Patrimonio en una doble vertiente, como elemento integrante de nuestro patrimonio documental y como soporte de ciertas inquietudes que nos han aproximado a la tutela del Patrimonio Histórico Español durante la Guerra Civil.

Bibliografía

Carteles de la República y la guerra civil. Barcelona, Gaya Ciencia, 1978.

Catálogo de carteles de la República y la Guerra Civil españolas. Madrid, Biblioteca Nacional, 1990.

Diccionario de Bibliología y Ciencias afines. Fundación Germán Sánchez Ruipérez, Madrid, 1989.

CARULLA, Jordi , CARULLA, Arnau: La guerra civil en 2.000 carteles: República, Guerra Civil, Postguerra. Barcelona, Postermil, 1977.

FERRER BENIMELI, José A.: "Archivo de la Guerra Civil de Salamanca". Historia 16 n.69, a.VII, pp. I09-I I5.

GRIMAU, Carmen: El cartel republicano en la guerra civil. Madrid, Cátedra, 1979.
JULIÁN, Inmaculada: El cartel republicano en la guerra civil española. Madrid, Ministerio de Cultura, 1993.

MARTÍN MARTíN, Fernando: El pabellón español en la Exposición Universal de París en 1937. Universidad de Sevilla, 1982.

MARTINEZ DE SOUSA, José: Diccionario de Bibliología y Ciencias afines. Barcelona, Gustavo Gili, 1990.

RENAU, Josep: Arte en peligro: 1936-39. Valencia, Fernando Torres, 1985.

RENAU, Josep: Función social del cartel. Valencia, Fernando Torres, 1976.

TOMÁS FERRE, Facundo: Los carteles valencianos en la guerra civil española. Ayuntamiento de Valencia, 1986. 